\title{
Simulation of thermal sanitization of air with heat recovery as applied to airborne pathogen deactivation
}

\author{
M. Busto ${ }^{1}$ E. E. Tarifa ${ }^{2}$ M. Cristaldi ${ }^{3} \cdot$ J. M. Badano ${ }^{1} \cdot$ C. R. Vera ${ }^{1}$ (I)
}

Received: 6 June 2021 / Revised: 28 November 2021 / Accepted: 10 January 2022 / Published online: 31 January 2022

(c) Islamic Azad University (IAU) 2022

\begin{abstract}
The technique of air sterilization by thermal effect was revisited in this work. The impact of incorporating a high efficiency heat recovery exchanger to a sterilizing cell was especially assessed. A mathematical model was developed to study the dynamics and the steady state of the sterilizer. Computer simulation and reported data of thermal inactivation of pathogens permitted obtaining results for a proof-of-concept. The simulation results confirmed that the incorporation of a heat recovery exchanger permits saving more than $90 \%$ of the energy needed to heat the air to the temperature necessary for sterilization, i.e., sterilization without heat recovery consumes 10-20 times the energy of the same sterilization device with heat recovery. Sanitization temperature is the main process variable for sanitization, a fact related to the activated nature of the thermal inactivation of viruses and bacteria. Heat recovery efficiency was a strong function of the heat transfer parameters but also rather insensitive to the cell temperature. The heat transfer area determined the maximum capacity of the sterilizer (maximum air flowrate) given the restrictions of minimum sanitization efficiency and maximum power consumption. The proposed thermal sterilization device has important advantages of robustness and simplicity over other commercial sterilization devices, needing practically no maintenance and eliminating a big variety of microorganisms to any desired degree. For most pathogens, the inactivation can be total. This result is not affected by the uncertainties in thermal inactivation data, due to the Arrhenius-like dependence of inactivation. Temperature can be adjusted to achieve any removal degree.
\end{abstract}

Keywords Air $\cdot$ Bacteria $\cdot$ Coronavirus $\cdot$ Spores $\cdot$ Thermal sanitization $\cdot$ Viruses

\author{
Abbreviations \\ WHO World Health Organization \\ HEPA High efficiency particulate arresting \\ UV Ultraviolet \\ RNA Ribonucleic acid \\ DNA Deoxyribonucleic acid
}

Editorial responsibility: Jing Chen.

C. R. Vera

cvera@fiq.unl.edu.ar

1 Institute of Research On Catalysis and Petrochemistry, INCAPE, FIQ-UNL, CONICET, Collecting Ring, National Road 168 km 0, El Pozo, 3000 Santa Fe, Argentina

2 Faculty of Engineering, Universidad Nacional de Jujuy, CONICET, Ítalo Palanca No. 10, 4600 San Salvador de Jujuy, Argentina

3 Av. Gob. Gregores \& Piloto Rivera, Universidad Nacional de La Patagonia Austral, 9400 Río Gallegos, Argentina

\section{Introduction}

During 2019-2021, severe acute respiratory syndrome coronavirus 2 (SARS-CoV-2), a new virus of the coronavirus family, spread throughout the world causing the so-called coronavirus disease (COVID-19) pandemic with a terrible death toll. During this time, there was a big discussion over the possibilities of contagion through the air. It was evident that the virus was transported in the drops and aerosols generated by sick people coughing or sneezing, and that it remained after some time on hard surfaces. Frequent hand sanitization, mask wearing and social distancing were the main measures against the spread of the virus. However, it was not initially clear whether droplet nuclei or the virus itself could remain suspended in the air for long periods of time. Some researchers then first reported that if small drops containing the SARS-CoV-2 virus particles reached the size of an aerosol (lower than 5 microns), they could remain suspended in the air for 0.5-3 h (Kern and Krishnan 2006). Later, more evidence was gathered, and it was concluded that aerosols could represent an important transmission pathway 
for SARS-CoV-2 because of many reasons (Shelton-Davenport et al 2020): (1) aerosols can contain infectious SARS$\mathrm{CoV}-2$, be transported many meters from the emitter and remain suspended in air for hours; (2) asymptomatic individuals are a source of aerosols with main sizes $<10 \mu \mathrm{m}$ and produce only a few droplets; (3) super-spreading events (events in which an infectious disease is spread much more than usual) can only be explained by aerosol transmission; (4) aerosols can lead to both close and long-range exposure if concentrated in a badly ventilated room.

Therefore, the possibility of contagion through air, even not in the proximity of a person with the virus, is possible. It would also be higher in hospital rooms or ambulances. For these and other places with a high possibility of finding a high virus concentration, decontamination of the room air should be mandatory. In the case of filtering, the best known technology is the use of HEPA (High Efficiency Particulate Arresting) filters that have a collection efficiency of $99.95 \%$ for particles with a size higher than $>0.3$ microns. Microorganisms may have quite different sizes depending on their origin. Generally speaking, fungal spores have $2-5$ microns; bacteria, $0.3-10$ microns; and viruses, $0.02-0.3$ microns (3M 2020; Levin and Angert 2015; Matthews 1975; Popov et al 2019; Reponen et al 2001).Some reported sizes of microorganisms are detailed in Table 1.

As it can be seen, HEPA filters can filter fungal spores and bacteria efficiently but may face problems filtering viruses. If the virus is contained in small droplets or aerosols not smaller than 0.3-0.5 microns, it will be suspended in air and eventually be retained in the filter. However, for smaller aerosol sizes, the filters could have a lower efficiency. It is in this case that methods based on virus deactivation could be a better choice. Almost all of them rely on first stages of suction of air and filtering of particles followed by a destructive treatment of the air stream. The treatment may involve ionization (Nunayon et al 2019), electric discharge (Pastuszka et al 2019), exposition to UV radiation (Krosney et al 2014), plasma treatment (Gallagher et al 2004), ozonization (Dubuis et al 2020), heating (Fiorenzano 1989, Matias 1999), etc.

Thermal sterilization is a known robust and proven technique for the destruction of germs, both pathogenic and non-pathogenic. In its common form, it has high energy consumption, and for this reason its application for the sanitization of air is disfavored in comparison with other alternative techniques, particularly filtration. Continuous thermal sterilization of air is a simple concept that was first introduced in 1950-1960, when the needs for supplying sterile air to biological reactors appeared (Humphrey 1960). Elsworth et al. (1955) reported that an air sterilizer operated at $300{ }^{\circ} \mathrm{C}$ and a minimum residence time of $1.6 \mathrm{~s}$ could reduce the penetration of spores suspended in air to 1 in 470 million. The basic idea of thermal sterilization is to heat the air stream to a sufficiently high temperature (sterilization temperature), and to keep it at that temperature for some time (sterilization time) in order to effectively inactivate the microorganism. These devices were mainly aimed at removing spores, bacteria and fungi and were later left aside in favor of other more energy efficient and less costly sterilization device. Small commercial devices can be found for the thermal elimination of suspended allergens and bacteria though their market penetration is small. Patents of such sterilization device are reported elsewhere (Fiorenzano 1989, Matias 1999).

The idea of thermal sterilization with a focus on virus inactivation is revisited in this work. In order to overcome the main problem of power consumption, an efficient heat integration between the inlet and outlet air streams is posed (see Fig. 1). Countercurrent heat transfer and a high surface area are expected to reduce the energy consumption, $Q_{\mathrm{b}}<<Q_{\mathrm{a}}$. Low values of energy consumed per unit of

Table 1 Reported sizes of some biologically hazardous microorganisms

\begin{tabular}{|c|c|c|c|c|c|}
\hline Microorganism & Size $(\mu \mathrm{m})$ & Ref & Microorganism & Size $(\mu \mathrm{m})$ & Ref \\
\hline Viruses & & & Bacteria & & \\
\hline SARS-CoV-2 & $0.07-0.09$ & (Kim et al 2020) & Mycobacterium tuberculosis & $1-5$ & $(3 \mathrm{M} 2020)$ \\
\hline Hepatitis B virus & $0.042-0.047$ & (Feng et al 2020) & Bacillus anthracis & $1.0-1.5$ & $(3 \mathrm{M} 2020)$ \\
\hline Human adenovirus 5 & $0.07-0.09$ & $(3 \mathrm{M} 2020)$ & Clostridium Botulinum & $\begin{array}{l}0.9-1.2 \text { (width) } \\
4-6 \text { (length) }\end{array}$ & $\begin{array}{l}\text { (Boerema } \\
\text { and Broda } \\
\text { 2004) }\end{array}$ \\
\hline $\begin{array}{l}\text { Alpha, Beta and Gamma influenza } \\
\text { virus }\end{array}$ & $0.08-0.012$ & $(3 \mathrm{M} 2020)$ & Fungal spores & & \\
\hline Hepatitis A virus & $0.028-0.030$ & $\begin{array}{l}\text { (Kern and Krishnan 2006; } \\
\text { Roberts et al 2010) }\end{array}$ & Batrachochytrium dendrobatidis & $\begin{array}{l}3-5 \text { (width) } \\
20 \text { (length) }\end{array}$ & (Anon 2017) \\
\hline Polio virus & 0.03 & (Kern and Krishnan 2006) & Aspergillus sydowii & $2.5-4$ & (Anon 2017) \\
\hline $\begin{array}{l}\text { Human immunodeficiency viruses } \\
\text { (HIV) }\end{array}$ & $>0.08$ & (Kern and Krishnan 2006) & & & \\
\hline Retroviridae & $0.08-0.13$ & (Roberts et al 2010) & & & \\
\hline
\end{tabular}



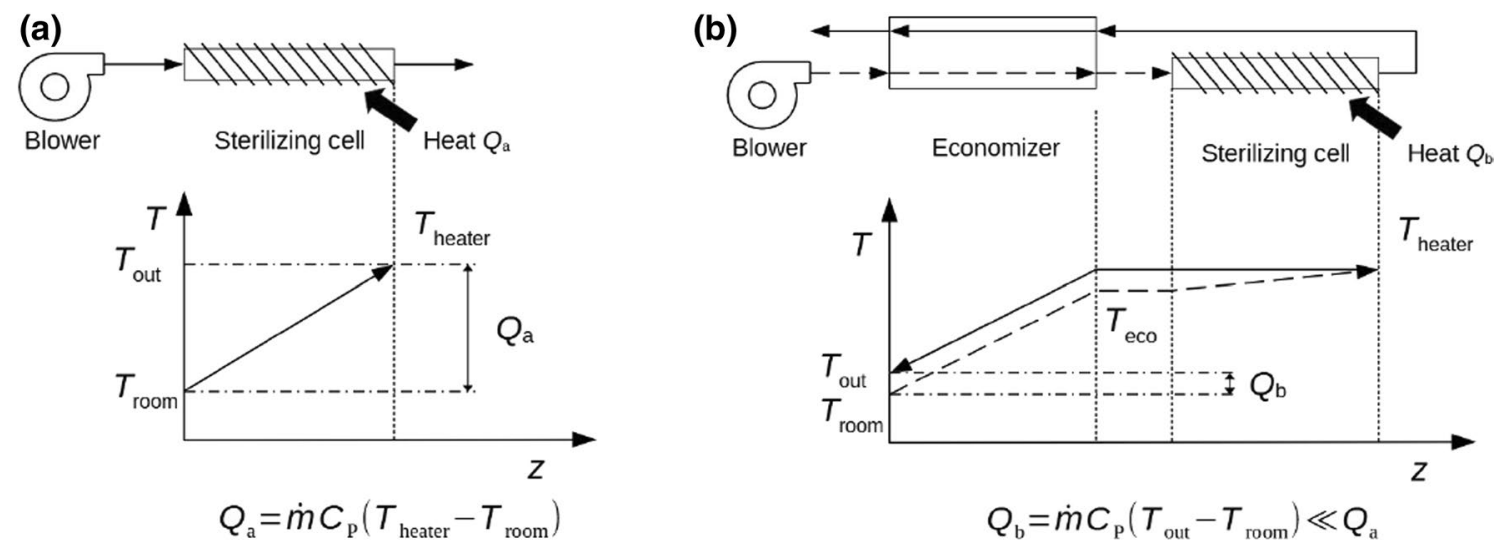

Fig. 1 Air sterilization by heat treatment. a Without heat recovery. b With heat recovery. The heat source is an electric coil. $\dot{m}$ is the mass flowrate of air, $C_{\mathrm{p}}$ is the specific heat capacity of air. $Q$ is the heat consumption of the sterilizer

processed volume could be obtained with an adequate design of the thermal sterilization cell and the heat exchanger economizer.

A dynamic model of the heat transfer and pathogen concentration as a function of time was built and solved in this work in order to extract the main features of the system. At this proof-of-concept stage, the idea of thermal sterilizer with efficient heat recovery was validated by simulation only. A full validation for bio-hazardous environments would demand a specialized laboratory with high safety levels that is out of the scope of this work.

This is a joint study performed at Universidad Nacional del Litoral (Santa Fe, Argentina), Universidad Nacional de Jujuy (San Salvador de Jujuy, Argentina) and Universidad Nacional de la Patagonia Austral (Río Gallegos, Argentina), from December 2020 to May 2021.

\section{Materials and methods}

\section{The sterilization device}

\section{Process description}

All magnitudes in the text and formulae will be expressed in SI units. The basic scheme of the sterilization device is depicted in Fig. 1. The air is forced into the sterilizer by a blower. The air first enters the economizer, i.e., the heat exchanger for heat recovery, and is heated there until the sterilization temperature is practically reached. Then, the air is passed through the sterilization cell where the heating is completed to the target sterilization temperature, i.e., $200-250{ }^{\circ} \mathrm{C}$. Then, the air is maintained at that temperature in the sterilization cell for an adequate amount of time. The residence time can be adjusted to a few fractions of a second or some seconds, depending on the resistance of the targeted microorganisms. Some examples of deactivation of microorganisms with different deactivation times will be given later in this work. The sterilization cell needs to be conveniently insulated to prevent thermal losses. Finally, the air goes out from the sterilization cell through the economizer where it exchanges heat with the inlet stream. The presence of a heat recovery economizer has been suggested in early proposed continuous sterilization processes for liquid streams (Pfeifer and Vojnovich 1952, Whitmarsh 1954).

The outlet temperature of the air is higher than the inlet temperature (room temperature). The magnitude of this temperature difference should be a function of the thermal efficiency of the economizer defined in Eq. (1).

$\varepsilon=1-\frac{Q_{\mathrm{b}}}{Q_{\mathrm{a}}}$

Appropriate equations for heat transfer and rate of removal of microorganisms will be written in order to make a model of the air sanitizer. Equations will be solved, and the influence of the process variables (air velocity, cell temperature) and sterilization device geometrical parameters (length-to-diameter ratio, surface area) will be assessed by means of simulation.

\section{Sterilization as a chemical reaction and pathogens as reactants}

Thermal sanitization is an activated process (Deindoerfer and Humphrey 1959). Deindoerfer (1957) early studied the sterilization of fermentation media and found that the reactivity in sterilization of microorganisms followed a simple Arrhenius law:

$r=k C$ 
$k=A e^{-\frac{E a}{R T}}$

where $C$ is the microorganism density, $r$ is the sterilization reaction rate, $k$ is the rate constant, $A$ is the pre-exponential factor, $E a$ is the activation energy, $R$ is the universal gas constant, and $T$ is the absolute temperature.

Deindoerfer (1957) reported the value of the activation energy for the death of Bacillus stearothermophilus and compared it with data of Levine (1956) and Garrett (1956) for other microorganisms and complex molecules. Values of $E a$ in $\mathrm{kJ} \mathrm{mol}^{-1}$ were folic acid $=70.3$, d-panthothenyl alcohol $=87.9$, cyanocobalamin $=96.6$, thiamine hydrochloride $=108.8$, Bacillus stearothermophilus strain $1518=283.2$, Clostridium sporogenes PA $3679=302.9$, Clostridium botulinum $=343.5$.

The different relative resistance of the microorganisms was long ago detected. Some microorganisms like thermophiles have optimal growth temperatures greater than $60^{\circ} \mathrm{C}$ and can withstand common sterilization techniques, like exposure to steam at $120{ }^{\circ} \mathrm{C}$ for several minutes, whereas others are easily killed. Rahn (1945) found that bacterial spores were orders of magnitude more resistant to moist heat than viruses and bacteriophages. Sauerbrei and Wutzler (2009)found that dry heat inactivated different viruses at different rates: poliovirus type $1>$ adenovirus type $5>$ polyoma virus SV $40>$ vaccinia virus $>>$ bovine parvovirus.

The fact that Eqs. (2) and (3) apply to thermal sanitization methods has a big impact on the operation of the sterilization device because small increases in the sterilization temperature lead to big increases in the processing rate and hence the processing capacity. On the other side too, low sterilization temperature can lead to incomplete sterilization of resistant microorganisms even at long treatment times. Transmission of B19 virus by ineffectively sterilized coagulation factors (treated with dry heat) has been reported in the literature (Santagostino et al 1997; Schneider et al 2004) despite of this treatment being broadly applied and being recommended for the inactivation of enveloped and non-enveloped viruses (Boschetti et al 2005).

For the choice of an adequate sterilization temperature and sterilization time, values of $A$ and $E a$ in Eq. (3) should be known for the target microorganisms. Many of these values have been collected from the literature sources and written in Table 2. With these values of the kinetic parameters, it is possible to integrate Eq. (2) to determine the time needed for a given percentage of inactivation of the microorganism at a given temperature. Most data on thermal resistance of microorganisms have been measured at temperatures lower than $150^{\circ} \mathrm{C}$. Therefore, any calculation at higher temperatures involves an extrapolation. In this sense, the mechanisms for thermal inactivation of microorganisms could be different in different temperature ranges, e.g., RNA denaturalization of viruses occurs at relatively low temperatures, while chemical reactions of the protein envelope are supposed to occur at higher temperatures.

An a priori screening of sterilization temperatures indicated that temperatures should be higher than $100-120^{\circ} \mathrm{C}$ in order to have high degrees of virus inactivation. A temperature of $150{ }^{\circ} \mathrm{C}$ was adopted in most of the simulations.

Most of the previous data have been taken from experiments with liquid suspensions of the viruses, and a few correspond to sterilization in hot dry air. The possibility of airborne presence of microorganisms is, however, not an assumption but a well-documented fact in the case of bacteria (Smets et al 2016), viruses (Cox 1989) and fungal spores (Streifel et al 1989).

Some examples of the needed sterilization time for different microorganisms at the same temperature and with the same inactivation degree can be calculated with the data of Table 2 and Eqs. (2-3). At $90{ }^{\circ} \mathrm{C}$, if $99.99 \%$ inactivation
Table 2 Heat resistance of different microorganisms. Values of the pre-exponential and activation energy of the constant $k$ of the first-order reaction of thermal inactivation. $k$ in $\min ^{-1}$

\begin{tabular}{llll}
\hline Microorganism & $\ln (A)$ & $E a\left(\mathrm{~kJ} \mathrm{~mol}^{-1}\right)$ & Refs \\
\hline Lipopolysaccharides & 24 & 96.7 & Tsuji and Harrison (1978) \\
Clostridium tetani (NCTC 5411 and 5413) & 23.9 & 151.8 & Darmady et al (1961) \\
Hepatitis A virus & 58.1 & 163.7 & Bozkurt et al (2014) \\
RNA viruses (Hemorrhagic fever) & 34.1 & 36.7 & Madani et al (2014) \\
SARS-CoV-2 & 48.6 & 135.7 & Yap et al (2020) \\
SARS-CoV-1 & 51.9 & 141.6 & Yap et al (2020) \\
Gastroenteritis Virus-RH50 & 36.8 & 106 & Yap et al (2020) \\
Clostridium Botulinum bacteria & 105.2 & 307.9 & Davey (1993) \\
Bacillus stearothermophilus spores & 108.7 & 349.8 & Wang et al (1964) \\
Bacillus stearothermophilus spores & 104.5 & 339.8 & Abraham et al (1990) \\
Bacillus ATCC 29,669 spores & 44.4 & 167.7 & Schubert and Beaudet (2011) \\
Escherichia Coli & 89.9 & 247.6 & Singh et al (2011) \\
Aspergillus Niger spores & - & $133-537$ & Fujikawa et al (2001) \\
Pichinde virus & - & $88.7-228$ & Allison et al (1985) \\
\hline
\end{tabular}


is demanded, 104, 23 and $14 \mathrm{~s}$ are needed for the RH50 transmissible gastroenteritis virus (a), Clostridium Botulinum bacteria (b) and SARS-Co-V2 virus (c). At $100^{\circ} \mathrm{C}$, the needed sterilization times are 40, 1.5 and $4.2 \mathrm{~s}$, respectively. It can be seen that the order of needed sterilization time $\left(t_{s}\right)$ at $90{ }^{\circ} \mathrm{C}\left(t_{s, a}>t_{s, b}>t_{s, c}\right)$ is altered at $100{ }^{\circ} \mathrm{C}\left(t_{s, a}>t_{s, c}>t_{s, b}\right)$ because of the differences in activation energy.

One obvious result from the inspection of Tables 1 and 2 is that spores of high thermal endurance have a much bigger size while viruses and bacteria of lower thermal resistance have a much smaller size. In this sense, thermal sanitization and filtration can be mutually complimentary. If a filter is placed before the thermal sanitizer, the microorganisms not retained in the filter can be inactivated at a relatively milder temperature.

As for the chemical reactions involved in thermal sterilization, they should be related to thermally activated reactions of the microorganism constituents, i.e., proteins and lipids. For example, a virus is made up of a core of genetic material, DNA or RNA, surrounded by a protective coat called a capsid which is made up of different proteins. The capsid is sometimes surrounded by an additional coat with spikes called the envelope. Proteins are large biomolecules formed by long chains of amino acids. For example, the coronavirus of the COVID-19 pandemic has a core of RNA chain join to nucleoproteins and lipid bilayer envelope with spike glycoproteins and other small proteins which have 76-109 amino acids (Schoeman and Fielding 2019).

Possible chemical changes could be: (1) Protein denaturation at temperatures higher than $60{ }^{\circ} \mathrm{C}$, heat treatment producing the disruption of the hydrogen bonds of the nonpolar hydrophobic interactions and of the electrochemical interactions, all of them responsible for the 3D organization of the protein; protein shape thus being lost. (2) Loss of non-structural water by evaporation at temperatures higher than $90-100{ }^{\circ} \mathrm{C}$. (3) Water and ammonia formation reactions from amino acids, mainly at $230-270{ }^{\circ} \mathrm{C}$ (Weiss et al 2018).

\section{The economizer and the cell}

The economizer is the heat recovery exchanger coupled to the sterilizing cell. The different reactions and temperature ranges pointed out in the previous paragraph suggest that some of the reactions might actually occur in the economizer rather than the sterilizing cell.

Apart from the hydraulic and heat transfer design, one basic problem is that of the choice of the material for constructing the economizer. Economizers are made with a variety of metals, but the most common are stainless steel, aluminum, copper, steel, brass. Air poses no corrosion problems. For efficient heat transfer, a good thermal conductor is appreciated and the values of this magnitude could be inspected (Abu-Eishah 2001) (conductivity in $\mathrm{W} \mathrm{m}^{-1} \mathrm{~K}^{-1}$ in brackets): aluminum (240), copper (400), iron (55), silver (420), high Cr-Ni stainless steel (15), bronze (50-100). Copper and aluminum have the highest thermal conductivity, whereas steel and bronze have the lowest. Silver is too expensive to be considered for the application.

Good thermal conductivity is an advantage, but too highly conductive materials may prove a bad choice too. Axial conduction in the direction of the gas flow and along the metal walls can prove to be detrimental to the heat integration if high values of heat recovery are needed. In this sense, stainless steel walls of small thickness in the economizer could provide a sufficiently low heat resistance while minimizing the axial conduction effect.

Another effect of the metal is its catalytic action for some reactions with sanitizing effect. Most metals have negligible effects, but silver and copper have been found to have sterilizing properties. Particularly, copper reduces the half-life of viruses and bacteria deposited on its surface at least one order of magnitude with respect to other materials (Michels et al 2015; Warnes et al 2015). No such effect is, however, expected at the short residence time values (few seconds) involved in air sterilization.

On the basis of good mechanical resistance, weldability and low cost, stainless steel is chosen as material for both the heat exchanger and the sterilizing cell.

In this work, an unbaffled shell-and-tube heat exchanger is used as an example of economizer (see Fig. 2). This choice is based on simplicity for calculation for a proof-of-concept design. This kind of sterilization device could anyway have some advantages for maintenance since it can be easily disassembled and cleaned to remove deposits of organic material and dust. The sterilization cell is designed as one tube homogeneously heated by an electrical resistance.

\section{The target space}

The air sterilizer can be placed in many target spaces like hospital rooms, ambulances, etc. For hospital rooms, recommended ventilation rates for clearance of pathogens are $\mathrm{ACH}=10-12 \mathrm{~h}^{-1}$ and minimum ventilation periods of

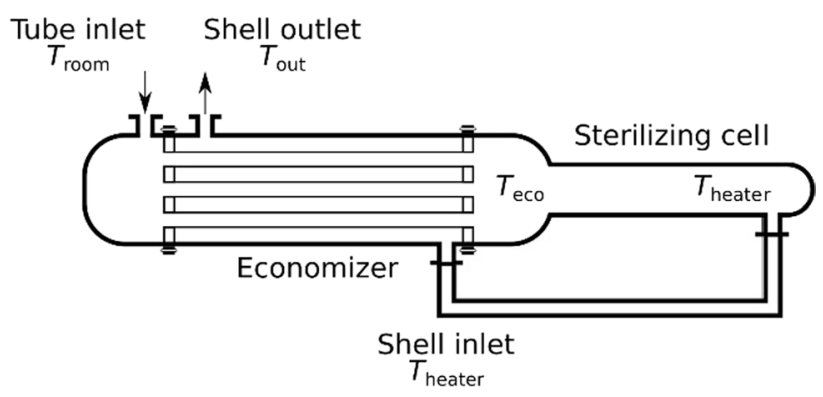

Fig. 2 Example of implementation of the sterilization cell with heat recovery. Economizer is a shell-and-tube heat exchanger in this case 
20 min or higher (Public Health England 2020). ACH is the number of changes of the volume of the system per hour. Once the $\mathrm{ACH}$ and the volume of the target space are indicated, the resulting air flowrate can be used for the design and optimization of the air sterilizer. An ACH of 1-10 $\mathrm{h}^{-1}$ and a hospital room of $36 \mathrm{~m}^{3}$ were considered in the model, giving flowrates of $36-360 \mathrm{~m}^{3} \mathrm{~h}^{-1}$.

\section{The mathematical model}

In the proposed mathematical model, the cold air stream coming from the room is supposed to enter the economizer in the tubes side. The properties of this stream are denoted with the subscript " $i$ ". The hot air stream leaving the sterilizing cell is supposed to flow through the shell of the economizer, and their properties are denoted with the subscript "o". The properties of the wall of a tube are denoted with the subscript "w".

The model for the phenomena occurring in the countercurrent economizer is depicted in Eqs. (4)-(8). Equation (4) is the differential energy balance for the cold air in a tube. Equation (5) is the differential molar balance of the microorganism in a tube. Equation (6) is the differential energy balance for the wall of a tube. Equation (7) is the differential energy balance for the hot air stream (shell side), and Eq. (8) is the differential molar balance for the microorganisms in the shell side of the economizer.

$\frac{\partial T_{\mathrm{i}}}{\partial t}=-v_{\mathrm{i}} \frac{\partial T_{\mathrm{i}}}{\partial z}+\frac{h_{\mathrm{i}} P_{\mathrm{i}}}{A_{\mathrm{i}} \rho_{\mathrm{i}} C_{\mathrm{Pi}}}\left(T_{\mathrm{w}}-T_{\mathrm{i}}\right)$

$\frac{\partial C_{\mathrm{i}}}{\partial t}=-\frac{\partial\left(v_{\mathrm{i}} C_{\mathrm{i}}\right)}{\partial z}-r_{\mathrm{i}}$

$\frac{\partial T_{\mathrm{w}}}{\partial t}=\frac{1}{A_{\mathrm{w}} \rho_{\mathrm{w}} C_{\mathrm{Pw}}}\left(h_{\mathrm{o}} P_{\mathrm{o}}\left(T_{\mathrm{o}}-T_{\mathrm{w}}\right)-h_{\mathrm{i}} P_{\mathrm{i}}\left(T_{\mathrm{w}}-T_{\mathrm{i}}\right)\right)$

$\frac{\partial T_{\mathrm{o}}}{\partial t}=v_{\mathrm{o}} \frac{\partial T_{\mathrm{o}}}{\partial z}-\frac{h_{\mathrm{o}} P_{\mathrm{o}}}{A_{\mathrm{o}} \rho_{\mathrm{o}} C_{\mathrm{Po}}}\left(T_{\mathrm{o}}-T_{\mathrm{w}}\right)$

$\frac{\partial C_{\mathrm{o}}}{\partial t}=\frac{\partial\left(v_{\mathrm{o}} C_{\mathrm{o}}\right)}{\partial z}-r_{\mathrm{o}}$

$T$ is the temperature, $v$ is the air velocity, $h$ is the heat transfer coefficient, $P$ is the tube perimeter, $A$ is the flow cross-sectional area, $\rho$ is the air stream density, $C_{\mathrm{P}}$ is the air specific heat capacity at constant pressure, $C$ is the concentration of microorganisms and $r$ is the sterilization rate.

The model for the sterilizing cell (or heater) is depicted in Eqs. (9-11). Variables for the heater are denoted with the "h" subscript. $\frac{\partial T_{\mathrm{wh}}}{\partial t}=\frac{1}{A_{\mathrm{wh}} \rho_{\mathrm{wh}} C_{\mathrm{Pwh}}}\left(\frac{Q}{L_{\mathrm{h}}}-h_{\mathrm{h}} P_{\mathrm{h}}\left(T_{\mathrm{wh}}-T_{\mathrm{h}}\right)\right)$

$\frac{\partial T_{\mathrm{h}}}{\partial t}=-v_{\mathrm{h}} \frac{\partial T_{\mathrm{h}}}{\partial z}+\frac{h_{\mathrm{h}} P_{\mathrm{h}}}{A_{\mathrm{h}} \rho_{\mathrm{h}} C_{\mathrm{Ph}}}\left(T_{\mathrm{wh}}-T_{\mathrm{h}}\right)$

$\frac{\partial C_{\mathrm{h}}}{\partial t}=-\frac{\partial\left(v_{\mathrm{h}} C_{\mathrm{h}}\right)}{\partial z}-r_{\mathrm{h}}$

Equations (9) and (10) are the differential energy balance in the wall and in the air stream, respectively. Equation (11) is the differential molar balance of the microorganism in the sterilizing cell. $Q$ is the input power, and $L_{\mathrm{h}}$ is the heater length.

The initial conditions are depicted in Eqs. (12) and (13) in which $z_{\mathrm{e}}$ and $z_{\mathrm{h}}$ are the axial coordinates of the economizer and the heater, respectively, and $T_{\text {room }}$ is the room temperature.

$T_{\mathrm{i}}=T_{\mathrm{o}}=T_{\mathrm{h}}=T_{\text {room }} \quad t=0, \forall z_{\mathrm{e}}, \forall z_{\mathrm{h}}$

$C_{\mathrm{i}}=C_{\mathrm{o}}=C_{\mathrm{h}}=0 \quad t=0, \forall z_{\mathrm{e}}, \forall z_{\mathrm{h}}$

Boundary conditions must be written at the entrance, Eqs. (14) and (15), outlet, Eqs. (16) and (17), and at the points connecting the heater to the economizer, Eqs. (18)-(19). $T_{\text {eco }}$ and $C_{\text {eco }}$ are the temperature and the microorganism concentration of the stream leaving the economizer tubes. $C_{\text {room }}$ is the microorganism concentration in the room air. $T_{\text {heater }}$ and $C_{\text {heater }}$ are the temperature and the microorganism concentration of the stream leaving the heater. $L_{\mathrm{e}}$ is the economizer length. $T_{\text {out }}$ and $C_{\text {out }}$ are the temperature and the microorganism concentration of the sterilized air stream at the exit.

$T_{\mathrm{i}}=T_{\text {room }} \quad z_{\mathrm{e}}=0, t>0$

$C_{\mathrm{i}}=C_{\text {room }} \quad z_{\mathrm{e}}=0, t>0$

$T_{\mathrm{i}}=T_{\mathrm{h}}=T_{\text {eco }} \quad z_{\mathrm{e}}=L_{\mathrm{e}}, z_{\mathrm{h}}=0, t>0$

$T_{\mathrm{o}}=T_{\mathrm{h}}=T_{\text {heater }} \quad z_{\mathrm{e}}=L_{\mathrm{e}}, z_{\mathrm{h}}=L_{\mathrm{h}}, t>0$

$C_{\mathrm{i}}=C_{\mathrm{h}}=C_{\text {eco }} \quad z_{\mathrm{e}}=L_{\mathrm{e}}, z_{\mathrm{h}}=0, t>0$

$C_{\mathrm{o}}=C_{\mathrm{h}}=C_{\text {heater }} \quad z_{\mathrm{e}}=L_{\mathrm{e}}, z_{\mathrm{h}}=L_{\mathrm{h}}, t>0$

$T_{\text {out }}=T_{\mathrm{o}} \quad z_{\mathrm{e}}=0, t>0$

$C_{\text {out }}=C_{\mathrm{o}} \quad z_{\mathrm{e}}=0, t>0$ 
The input power $Q$ should not be constant but rather subjected to a control scheme. A simple proportional control scheme (Luyben 1990) is written in Eqs. (22)-(23). $A c_{\mathrm{T}}$ is the proportional control action, $A b_{\mathrm{T}}$ is the bias, $k_{\mathrm{P}}$ is the proportional gain, $e_{\mathrm{T}}$ is the error, $x_{\mathrm{T}}$ is the limited control signal, $T_{\mathrm{sp}}$ is the setpoint, and $Q_{\max }$ is the maximum power delivered by the heater.

$A c_{\mathrm{T}}=A b_{\mathrm{T}}+k_{\mathrm{P}} e_{\mathrm{T}}$

$e_{\mathrm{T}}=T_{\mathrm{sp}}-T_{\text {heater }}$

$x_{\mathrm{T}}= \begin{cases}0 & A c_{\mathrm{T}} \leq 0 \\ A c_{\mathrm{T}} & 0 \leq A c_{\mathrm{T}}<1 \\ 1 & A c_{\mathrm{T}} \geq 1\end{cases}$

$Q=x_{\mathrm{T}} Q_{\max }$

The system of Eqs. (4)-(21) was numerically solved by discretizing the heat recovery exchanger into $(N-1)$ intervals and the sterilizing cells also into $(N-1)$ intervals. Partial derivatives were replaced by finite differences. In this way, the system was reduced to a system of first-order ODEs depicting the variation of the temperature and concentration of microorganisms in each node.

Pressure drop $(\Delta P)$ in the tubes, in the sterilizing cell and in the shell was calculated by using Eq. (26). The friction factors $f$ were calculated with the correlations due to Bhatti and Shah (Kakaç et al 1988), Eq. (27). For the shell, the same equation was used but changing the normal diameter $D$ by the hydraulic equivalent diameter. The value of the total pressure drop was used for calculating the power for moving the air through the sterilizer but not for correcting the pressure in the equations of the differential energy and mass balances. It was considered that if the pressure drop was not significant, a correction was not needed. Heat transfer coefficients for turbulent flow were obtained from the correlation of Sleicher and Rouse (Sleicher and Rouse 1975), Eqs. (28-30). For laminar Reynolds, a constant $\mathrm{Nu}=4.364$ was considered.

$\Delta P=f \frac{\rho L v^{2}}{D}$

$f=a+b \operatorname{Re}^{-\frac{1}{m}}$

$\mathrm{Nu}=5+0.012 \operatorname{Re}^{0.83}(\operatorname{Pr}+0.29) \varphi$

$\varphi=\left(\frac{T_{\mathrm{w}}}{T}\right)^{n}$ $n=-\log _{10}\left(\frac{T_{\mathrm{w}}}{T}\right)^{0.25}+0.3$

The tasks of simulation and equation solving were performed in GNU Octave for Windows. With respect to the control of the accuracy of the method, discretization was increased until an error lower than 5\% was found in the global thermal balance between the hot and cold streams of the economizer. Time integration of all dependent variables was performed with a relative tolerance of $10^{-6}$.

\section{Influence of the axial conduction through the metal}

In Eq. (6), a term including the transfer of heat by conduction along the metal walls was not written. Heat transfer degradation due to axial conduction of heat is, however, possible. In this sense, some authors (Baek et al 2012; Kroeger 1967) have obtained full solutions for countercurrent plate-fin heat exchangers and plotted efficiency or inefficiency in terms of the $\lambda$ parameter, Eq. (31), $C_{\min } / C_{\max }$ and the NTU. $C_{\min }$ and $C_{\max }$ are the minimum and maximum heat capacity rates (in $\mathrm{W} \mathrm{K}^{-1}$ ) of the streams, and NTU is the number of transfer units, Eq. (32). For a countercurrent heat exchange between two streams of equal heat capacity rate, as in the air sterilizer, $C_{\min } / C_{\max }=1$, and the flow is said to be "balanced". For balanced flows, the authors predict that for NTU $>20$ and $\lambda<0.02$, the efficiency $\varepsilon$, Eq. (33) is greater than $95 \%$.

$\lambda=\frac{k_{\mathrm{w}} A_{\mathrm{w}}}{L C_{\min }}$

$\mathrm{NTU}=\frac{U A_{\mathrm{t}}}{\left(\rho F_{\mathrm{v}} C_{\mathrm{P}}\right)_{\text {min }}}$

$\varepsilon=1-\frac{T_{\text {out }}-T_{\text {room }}}{T_{\text {sp }}-T_{\text {room }}}$

$A_{\mathrm{t}}$ is the total area for heat transfer of the heat exchanger. $U$ is the global heat transfer coefficient. $k_{\mathrm{w}}$ and $A_{\mathrm{w}}$ are thermal conductivity and total cross area of the metal walls.

Inspection of the definition of $\lambda$ shows that too high thermal conductivity metals can bring problems to the efficiency of the heat exchanger, and that high $L / A_{\mathrm{w}}$ sterilization device has an advantage. In this sense, the axial conduction can be reduced if $L$ is increased and $A_{\mathrm{w}}$ decreased. For tubular heat exchangers, this implies a high $L / D$ ratio.

The system was not modeled with axial conduction, and heat transfer efficiency was kept high by adopting exchanger configurations with $\lambda$ lower than 0.02 . 


\section{Results and discussion}

The sterilizer is supposed to be placed in a small room with $36 \mathrm{~m}^{3}$ of air volume. In order to accurately calculate the air properties, they were interpolated from tabulated experimental values (Green and Perry 2008). Properties of the system are detailed in Table 3. A full solution of the system, Eqs. (2-25), using the finite differences method, is presented in the upcoming figures.

About $2 \mathrm{~h}$ are needed to reach the steady state. This is checked by inspection of the temperature traces of Fig. 3(a, b) and the power consumption plot of Fig. 3d. Figure $3 \mathrm{c}$ shows the steady-state temperature traces of the economizer.
Table 3 Values of the process variables and design parameters of the sterilization device in the basic example

\section{Economizer}

Tubes length, $L_{\mathrm{e}}(\mathrm{m})$

Shell diameter $(\mathrm{m})$

Number of tubes

Tubes outer diameter (m)

Tubes thickness (m)

Tubes material

Simulation

$z$ nodes, economizer

$z$ nodes, sterilizing cell

Simulation total time (h)

\section{Process variables}

Room temperature, $T_{\text {room }}\left({ }^{\circ} \mathrm{C}\right)$

25

Temperature set point, $T_{\mathrm{sp}}\left({ }^{\circ} \mathrm{C}\right)$

200-300

300-9000

36-360

Air flowrate, $F_{\mathrm{v}}\left(\mathrm{m}^{3} \mathrm{~h}^{-1}\right)$

\section{Sterilizing cell}

Length, $L_{\mathrm{h}}(\mathrm{m})$

2

Internal diameter (m)

0.034

Wall thickness (mm)

1

Steel
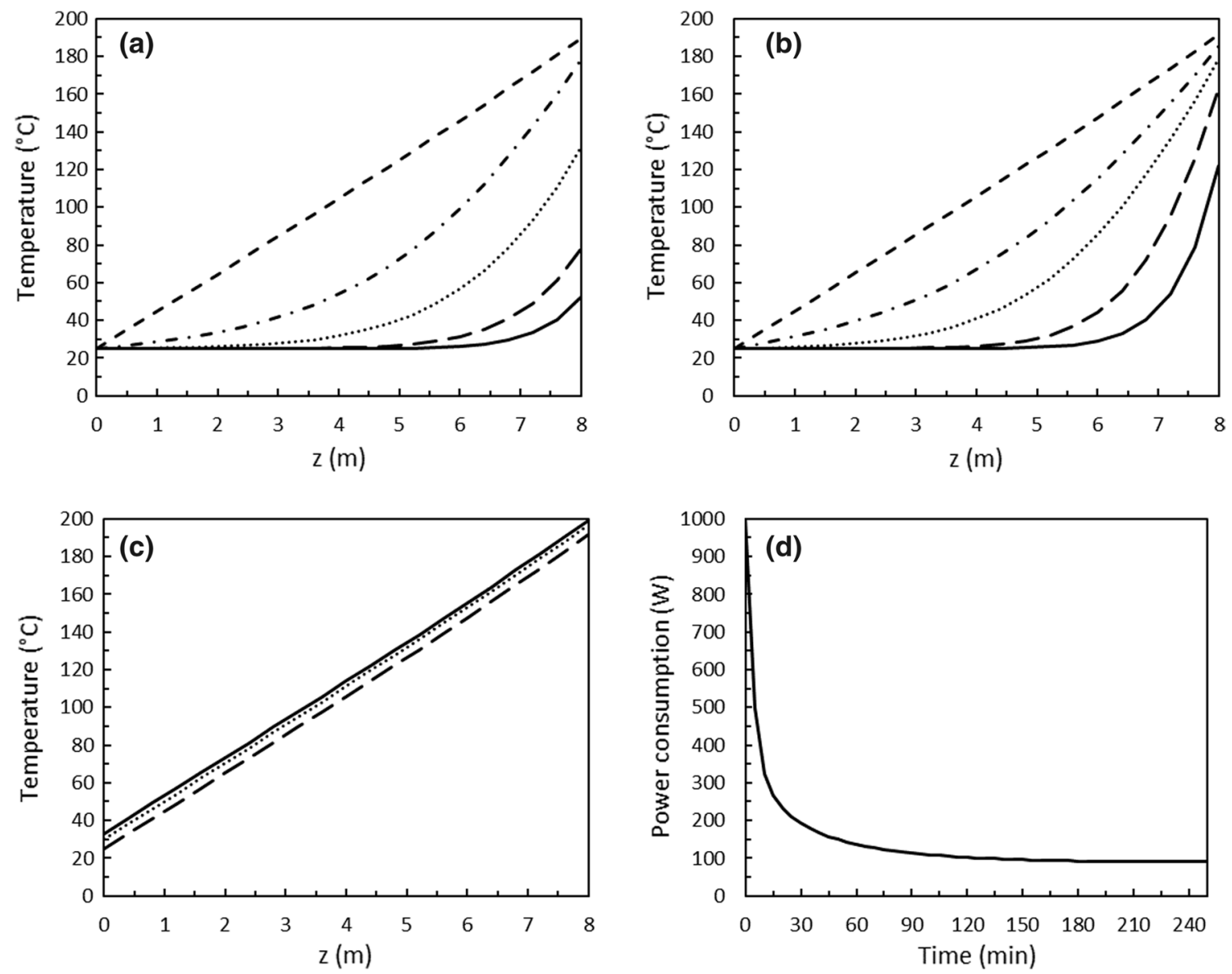

Fig. 3 Economizer temperature $(T)$ as a function of position $(z)$ and time $(t)$. a $T$ versus $z, T_{\mathrm{sp}}=200{ }^{\circ} \mathrm{C}, F_{\mathrm{v}}=36 \mathrm{~m}^{3} \mathrm{~h}^{-1}, Q_{\max }=300 \mathrm{~W} . \mathbf{b} \operatorname{Idem}$, $Q_{\max }=1 \mathrm{~kW}$. c $T$ versus $z$, steady-state. d Power as a function of $t, Q_{\max }=1 \mathrm{~kW}$ 
These are perfectly linear. This is typical of economizers of autothermal reactors that have equal mass flow rates in both sides (Froment et al 2010). However, during the transient period, the traces have a parabolic-like pattern. Depending on the maximum power of the heater, the temperature of the cell can rapidly reach the setpoint like in (b). The heater setpoint is always reached before the economizer reaches the steady state.

Energy consumption is the summation of two components. The first one is the net heating power consumed, i.e., power transmitted to the cold stream minus the power recovered in the economizer. The second one is the energy consumed by the blower that moves the air through the sterilizer.

During the warming-up of the device, the value of the power consumption is initially the maximum power available $\left(Q_{\max }\right)$. In the steady state, the consumption is $96 \mathrm{~W}$, i.e., only $10 \%$ of the maximum value, Fig. 3 d. The consumed power is proportional to the temperature difference between the inlet and outlet air streams. The temperature difference is $8.2{ }^{\circ} \mathrm{C}$. This temperature corresponds to an efficiency of heat recovery in the economizer of $\varepsilon=95.3 \%$. The efficiency is defined in Eq. (33). The pressure drop in the sterilizer is $70 \mathrm{mbar}$ and the pumping power, $70 \mathrm{~W}$. The flow inside the sterilizer is laminar, Re about 2000, and the heat transfer coefficients are rather low, about $40 \mathrm{~W} \mathrm{~m}^{-2} \mathrm{~K}^{-1}$.

With the chosen air sterilization rate for the example of Fig. 3, the air volume of a big room, like that of an intensive care room, could be sterilized in $1 \mathrm{~h}$. The sterilization effectiveness depends on the thermal death rate along the sterilizer. Figure 4 shows traces of the $C / C_{\text {room }}$ ratio during the sterilization of some known viruses. SARS-CoV-2 and the other two checked viruses are practically dead at the entrance of the sterilizing cell, i.e., all virus entities have been killed when heating from room temperature to $200{ }^{\circ} \mathrm{C}$. The death rate becomes significant at $5 \mathrm{~m}$, corresponding

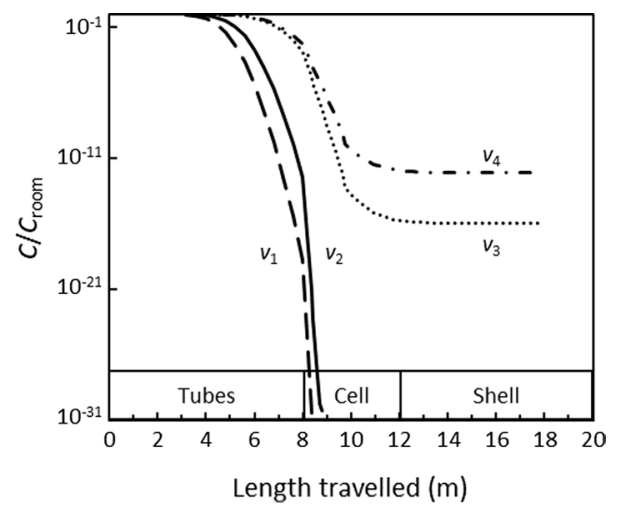

Fig. 4 Thermal death of viruses. Relative concentration in air as a function of the length along the sterilizer. SARS-CoV-1 virus $\left(v_{1}\right)$, SARS-CoV-2 virus $\left(v_{2}\right)$, Transmissible Gastroenteritis Virus-RH50 $\left(v_{3}\right)$, Hemorrhagic fever virus $\left(v_{4}\right)$ to a tube temperature of $120{ }^{\circ} \mathrm{C}$. The rate is, however, negligible for lengths lower than $4 \mathrm{~m}$, when the temperature is lower than $100{ }^{\circ} \mathrm{C}$.

The results of high degree of virus deactivation of Fig. 4 are a consequence of the values of the pre-exponential factor and activation energy of the kinetic constant of thermal death of Table 2. Positive or negative deviations could possibly be found in a real experiment, but the global pattern is expected to be the same. If the real pathogen deactivation degree was found to be low, its value could be easily tuned by small changes in the cell temperature due to the very high sensitivity of the Arrhenius-like thermal death rate. In this sense, real-life experiments to refine the model could be spared due to the robust adaptability of the system.

Discretization of the $z$ domain introduced a small error. To assess this error, an integral heat balance of the economizer was made at steady-state conditions. The result indicated that the error was $6 \%$ for $N$ (number of nodes) equal to $20,4 \%$ for $N=40,2 \%$ for $N=100$ and $1 \%$ for $N=200$. $N=200$ was adopted for most calculations.

The heat recovery efficiency and the pressure drop were found to be strong functions of the air flow rate. If 3-6 room air replacements by hour were the target, then the flow rate must be increased 3-6 times with respect to the base case, and the pressure is especially sharply increased. Figure 5 shows this.

Increasing the flow rate has advantages and disadvantages. If heater cell and residence time are adequate for virus inactivation, as in this case, the only limitations for increasing the air sterilization capacity are the heating and pumping power. Figure 5 shows that increasing the air velocity also increases the heat transfer coefficient, which is good for maintaining the efficiency for heat recovery in all cases $(\approx 95 \%)$ despite the higher flow rate. However, both heating

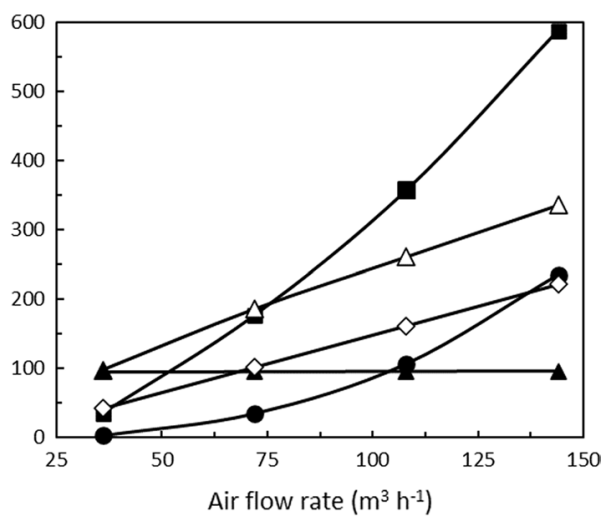

Fig. 5 Influence of flow rate on process properties (virus destruction $>99.9999 \%$ ). (filled square) Pressure drop (mbar), (filled circle) Pumping power $\times 0.1(\mathrm{~W})$, (open triangle) Heating power $(\mathrm{W})$, (filled triangle) Heat recovery efficiency $\varepsilon(\%)$, (diamond symbol) Heat transfer coefficient $\left(\mathrm{W} \mathrm{m}{ }^{-2} \mathrm{~K}^{-1}\right)$ 
power and pumping are also increased. As the flowrate is increased four times, the heating power is increased three times. The heating power consumption per unit flow rate (W per $\mathrm{m}^{3} \mathrm{~h}^{-1}$ ) is therefore almost not affected. The pumping power is, however, greatly increased from 36 to $2300 \mathrm{~W}$, and the pressure drop goes from 36 to 588 mbar. It is clear that the main limitation for the use of the sterilizer is the pressure drop at high flow rates. This consequence is unavoidable because narrow channels appear naturally in high surface area geometries needed for efficient heat recovery. The maximum air sterilization rate with acceptable pressure drop seems to be about $100 \mathrm{~m}^{3} \mathrm{~h}^{-1}$. For this condition, the temperature of the sterilized air is $7.3{ }^{\circ} \mathrm{C}$ hotter than the room temperature.

The influence of the ratio of the heat transfer area to the area for air flow $(\beta)$ is depicted in Fig. 6. High $\beta$ ratios favor the heat recovery, lowering the consumption of thermal power. However, the main problem is again the steep increase in the pumping power and pressure drop as the area for air flow is reduced. Values of the $\beta$ ratio higher than 10,000 seem prohibitive in terms of pumping power. On the other side, values lower than 5000 increase the heating power also too much and increase the sterilized air temperature more than $15^{\circ} \mathrm{C}$ over the room temperature (low heat recovery). This is due to the low value of the heat transfer coefficients in the region of laminar flow at small $\beta$ ratios.

Finally, the influence of the temperature of the heater should be assessed. A plot similar to that of Fig. 4 is included in Fig. 7. Now, the thermal death traces for SARSCoV-2 and Bacillus sp. ATCC 29,669, at three different temperatures, are included. The indicated spores have one of the highest thermal resistance recorded in hot air (Schubert and Beaudet 2011).

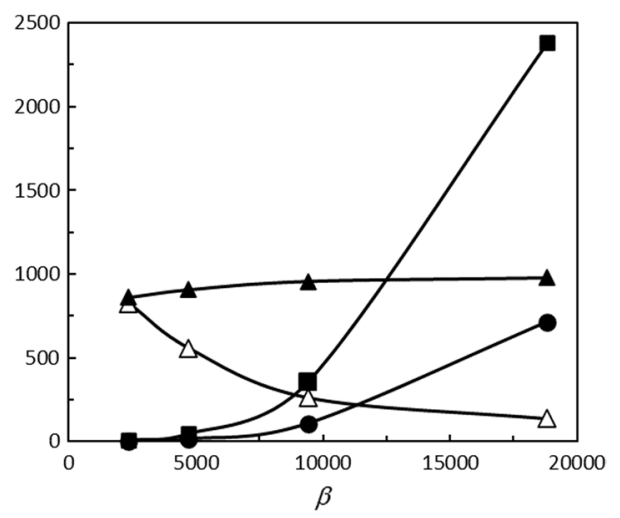

Fig. 6 Influence of $\beta=$ heat transfer area/flow area. Constant heat transfer area, other conditions as in Table $3, F_{\mathrm{v}}=108 \mathrm{~m}^{3} \mathrm{~h}^{-1}$. (filled square) Pressure drop (mbar). (filled circle) Pumping power $\times 0.1$ $(\mathrm{W})$. $(\Delta)$ Heating power $(\mathrm{W})$. (filled triangle) Heat recovery efficiency $\times 1000$

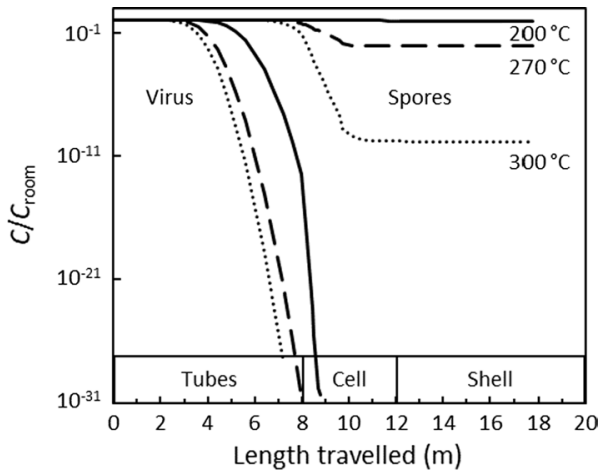

Fig. 7 Influence of the sterilizing cell temperature. $200{ }^{\circ} \mathrm{C}$ (solid line), $270{ }^{\circ} \mathrm{C}$ (dash line), $300{ }^{\circ} \mathrm{C}$ (dotted line). Air flow rate of 36 $\mathrm{m}^{3} \mathrm{~h}^{-1}$. Rest of the data as in Table 3

The results indicate that the heater temperature must be increased to $300{ }^{\circ} \mathrm{C}$ to kill all spores, but $200{ }^{\circ} \mathrm{C}$ is enough for deactivating SARS-CoV-2. In the case of the spores, the length of the sterilizing cell could be increased to achieve a reduction of $10^{6}$ in the $C / C_{\text {room }}$ ratio. Increasing the temperature from 200 to $300{ }^{\circ} \mathrm{C}$ does not modify the heat recovery efficiency, which stays at the same value of $95.4 \%$. The temperature of the sterilized air is, however, increased due to the higher temperature difference between the cell and the room temperatures. At $300{ }^{\circ} \mathrm{C}$, there is a $12{ }^{\circ} \mathrm{C}$ difference between the room air and the sterilized air.

The results so far shown indicate that the heat recovery efficiency depends only on the flow dynamics and the available surface area. For this reason, it is advantageous to keep a rather high cell temperature to increase the thermal death rate and hence the sterilizing capacity. A high thermal death rate reduces the needed residence time and then a given sterilization efficiency can be got with a shorter cell and shorter economizer. The logic of better short-time high temperature than long-time low temperature seems clear.

\section{Comparison with other sanitization devices}

Many technologies have emerged in the last years that perform the sanitization of air. Among them, UV treatment and filtering are the most common. With respect to the latter, some kind of filtering is included in most applications but single filtering can be a stand-alone technique if HEPA filters are used.

- UV. Advantages: medium energy consumption; high efficiency if coupled with HEPA filtration. Disadvantages: relatively high maintenance cost (lamp replacement); few reports on virus removal efficiency; low efficiency for removing spores. Examples: (a) fungi and bacteria with $2-110 \mathrm{CFU} \mathrm{m} \mathrm{m}^{-3}$ in rooms, removal of $78 \%$ fungi and $62 \%$ bacteria (continuous flow UV sterilizer + fil- 
ter, air flowrate, $0.11 \mathrm{~m}^{3 \mathrm{~s}-1}, 0.11$ units $\left.\mathrm{m}^{-2}\right)$ (Guimera et al 2018). (b) Removal of 90\% Serratia (bacillus) and 99.99\% Aspergillus (fungus) (continuous flow UV sterilizer + filter, air flowrate $4.5 \mathrm{~m}^{3} \mathrm{~s}^{-1}, 72 \mathrm{~W}$ lamps, $0.5 \mathrm{~s}$ exposure time, $413 \mathrm{~m} \mathrm{~s}^{-1}$ air speed, $3744 \mathrm{~h}$ lamp life (Kowalski and Bahnfleth 2000). (c) $99.5+\%$ removal of Staphylococcus aureus, Staphylococcus epidermidis, Serratia marcescens, Bacillus subtilis, $67 \%$ removal of Aspergillus niger (continuous flow UV sterilizer + filter, $0.5 \mathrm{~s}$ irradiation time, $254 \mathrm{~nm}$ UV lamps) (Nakamura 1987).

- Ionization. Advantages: - Disadvantages: Few reports on virus removal efficiency. Examples: $99+\%$ removal of Staphylococcus aureus with ionic breeze air purifier, $6 \mathrm{~h}$ discontinuous operation (Ko and Burge 2007).

- Cold plasma. Advantages: - Disadvantages: - Examples: a) 20-70\% removal of Escherichia coli, Pseudomonas alcaligenes, Staphylococcus epidermidis (cold plasma continuous sanitizer, $2-7 \mathrm{~m} \mathrm{~s}^{-1}$ air velocity) (Lai et al 2016). b) room with $6000 \mathrm{CFU} \mathrm{m}^{-3}, 31-89 \%$ removal of Escherichia coli (plasma + ionic wind, $4.5 \mathrm{~m} \mathrm{~s}^{-1}$ air velocity) (Prehn et al 2020).

- Filtration. Advantages: Low energy consumption. High efficiency for bacteria and fungi. Disadvantages: Inefficient filtration of viruses in small aerosols. Filters must be disposed as hazardous medical waste. Needs UV germicidal irradiation if growth of microorganisms on surfaces is to be stopped. Need of prefilters to avoid clogging by dust and particulate. Laminar flow demands air velocities of $0.3-0.5 \mathrm{~m} \mathrm{~s}^{-1}$ leading to big filter areas. Filter replacement can be frequent. Examples: (a) Aerosolized suspensions of $10^{4} \mathrm{~mL}^{-1}$ Staphylococcus aureus, $10^{4} \mathrm{~mL}^{-1}$ Escherichia coli, $10^{8} \mathrm{~mL}^{-1} \mathrm{~T} 7$ virus; $99+\%$ removal (commercial electronic air filter, aerosol size not given) (Malaithao et al 2009). (b) $10^{5} \mathrm{CFU}$ in air; $99.97 \%$ removal of MS2 Coli phagus virus (continuous air purifier with HEPA filter, air velocity of $2 \mathrm{~cm} \mathrm{~s}^{-1}$, aerosol size not given) (Wilkes et al 2000). c) $95+\%$ removal of virus with aerosol diameters of $0.25-1 \mu \mathrm{m}$; practically $100 \%$ for diameters higher than $2.5 \mu \mathrm{m}$ SARS-CoV-2 aerosols are about $30-90 \%$ smaller than 0.25 microns depending on sampling place; continuous air purifiers with HEPA filter, 0.1-0.28 Watt $\left(\mathrm{m}^{3} \mathrm{~h}^{-1}\right)^{-1}$; filters recommended to be collected and disposed as hazardous medical waste; intensive care unit with virus emission of 31-113 copies $\mathrm{m}^{-3} \mathrm{~h}^{-1}$ (Chen et al 2019; Liu et al 2020).

- Heat. Advantages: high removal rates possible; robust, simple construction and operation; practically no maintenance needed except for cleaning; high air velocities possible. Disadvantages: high power consumption if no economizer is used; heat is dissipated into the room; important pressure drop in heat recovery exchanger. Example: removal of $99.9999+\%$ virus, $99.9999+\%$, bacteria $99+\%$ fungi; tubular thermal sanitizer, 36-144 $\mathrm{m}^{3} \mathrm{~h}^{-1}, 150-250{ }^{\circ} \mathrm{C}$ cell temperature (this work).

Filtration and thermal treatment seem to be the alternatives with maximum efficiency for a wide set of pathogens in air. Main advantage for filtration is the low energy consumption, while its main disadvantages are bacteria growth, probable incomplete removal of small viruses and frequent maintenance and replacement. For thermal sterilizers, the main advantage is robustness and small maintenance, while high pressure drop in the economizer at high air flow rates seems to be the main disadvantage.

\section{On the practical application of thermal deactivation}

The thermal sanitizer was designed to be used in hospital rooms. These are contaminated, closed places with likely hazardous concentrations of known pathogens. A hazardous concentration is one that leads to an intake dose higher than the minimum infective dose for a short time of residence in the room, e.g., $10 \mathrm{~min}$. Intake should be calculated on the basis of a normal breathing frequency, i.e., $6 \mathrm{~L} \mathrm{~min}^{-1}$. Pathogens detection and identification should be performed with standard techniques such as air sampling and retention on filters, plaques, liquid impingers, followed by replication and counting (measurement of concentration) and visual inspection or specific testing (identification) (Pan et al 2019).

Sterilization of air is a dynamic process depending on the presence of multiple sources and sinks. Sources are contaminated people, e.g., patients in the room that emit pathogens through breathing and coughing. Sinks are related to settling of pathogen particles on room surfaces, natural death, withdrawal of air by ventilation, and sterilization itself (Hussein et al 2009; Riediker and Tsai 2020).

The air of the room is recycled through the sterilizer. This is a common feature with other flow-through systems, independent of the deactivation technique (UV, filtering, ozone, etc.). In the steady-state of a given system, the pathogens emission rate is equal to the sterilizing rate. Therefore, the sterilizer must be designed with a flowrate, cell temperature and residence time that allows balancing the emission rate. A simulation of a given situation is considered to be out of the scope of this article, but the general idea and the fundamental equations have been laid clear.

\section{Conclusion}

This work revisited the idea of air sterilization by heat treatment. The original idea of single sterilizing cell was modified by introducing high efficiency heat recovery with a countercurrent economizer. Fundamental data related to the kinetics of thermal inactivation of microorganisms were 
compiled from literature sources. The problem was mathematically analyzed, and then, transient and steady-state solutions for power consumption, temperature distribution and virus concentration were found by solving the corresponding equations numerically. The simulation results are considered a valid proof-of-concept. The main conclusions are:

- Big spores require rather high temperatures $\left(>270{ }^{\circ} \mathrm{C}\right)$ for thermal destruction, while smaller viruses and bacteria require lower temperatures for inactivation $\left(<200^{\circ} \mathrm{C}\right)$.

- The fundamental variable for thermal inactivation of microorganisms is the temperature. High-temperature short-time treatments are more convenient than low-temperature long-time ones, the latter leading to prohibitive big cell volumes.

- Despite the possible uncertainty in thermal death data, the Arrhenius dependence leads to an exponential growth of the death rate, enabling total removal by appropriate adjustments of the sanitizing temperature.

- The key solution for operating a thermal sterilizer with a relatively high temperature is the heat integration of the process streams. Efficient heat integration is achieved by high heat transfer areas and coefficients and a countercurrent flow pattern.

- An example of a shell-and-tube heat exchanger coupled to a sterilization cell was simulated. A sterilization device with a volume of about $26 \mathrm{~L}$ and $9 \mathrm{~m}^{2}$ heat transfer area sanitized air with a virus removal efficiency of $99.9999+\%$ with the cell operated at $200{ }^{\circ} \mathrm{C}$, a flow rate of $36 \mathrm{~m}^{3} \mathrm{~h}^{-1}$ and a heat recovery efficiency of $95 \%$.

- Thermal sanitization of air proves to be robust and simple and with a relatively small heat signature if efficiencies of heat recovery are greater than $90 \%$. Main problem is the relatively high pressure drop in the economizer at high flow rates.

Acknowledgments The authors wish to thank all who assisted in conducting this work.

Funding The authors thank the financial support of CONICET (Grant PIP 11220130100457CO), Universidad Nacional del Litoral (Grant CAI + D 50320190400344LI) and Universidad Nacional de Jujuy (Grant SeCTER D/0164).

Data availability All data generated or analyzed during this study are included in this published article.

\section{Declarations}

Conflict of interest The authors have no relevant financial or non-financial interests to disclose.
Ethical approval This article does not contain any studies with human participants performed by any of the authors.

\section{References}

3M (2020) Respiratory protection for airborne exposures to biohazards. Technical Data Bulletin. Saint Paul, EEUU: 3M, 1-10. https://multimedia.3m.com/mws/media/409903O/respiratoryprotection-against-biohazards.pdf Accessed 230820.

Abraham G, Debray E, Candau Y, Piar G (1990) Mathematical model of thermal destruction of Bacillus stearothermophilus spores. Appl Environ Microbiol 56(10):3073-3080

Abu-Eishah SI (2001) Correlations for the thermal conductivity of metals as a function of temperature. Int $\mathrm{J}$ Thermophys 22(6):1855-1868

Allison L, Salter M, Mann G, Howard CR (1985) Thermal inactivation of pichinde virus. J Virol Methods 11(3):259-264

Anon (2017) Long-distance dispersal of fungi. In: Heitman J, Howlett B, Crous PW, Stukenbrock E, James T, Gow NAR (eds) The Fungal Kingdom. American Society of Microbiology, 309-333. Available at: http://www.asmscience.org/content/book/https://doi. org/10.1128/9781555819583.chap14. Accessed 10 April 21

Baek S, Kim J-H, Jeong S, Jung J (2012) Development of highly effective cryogenic printed circuit heat exchanger (PCHE) with low axial conduction. Cryogenics 52(7-9):366-374

Boerema JA and Broda DM (2004) Microbiological safety of meat. Clostridium botulinum. Encycl Meat Sci. Elsevier, 786-793. https://linkinghub.elsevier.com/retrieve/pii/B012464970X0005 32. Accessed 10 April 21

Boschetti N, Stucki M, Späth PJ, Kempf C (2005) Virus safety of intravenous immunoglobulin: future challenges. Clin Rev Allergy Immunol 29(3):333-344

Bozkurt H, D’Souza DH, Davidson PM (2014) Determination of thermal inactivation kinetics of hepatitis A virus in blue mussel (Mytilus edulis) homogenate. Appl Environ Microbiol 80(10):3191-3197

Chen C, Ji W, Zhao B (2019) Size-dependent efficiencies of ultrafine particle removal of various filter media. Build Environ 160:106171

Cox CS (1989) Airborne bacteria and viruses. Sci Prog 73(292 Pt 4):469-499

Darmady EM, Hughes KEA, Jones JD, Prince D, Tuke W (1961) Sterilization by dry heat. J Clin Pathol 14(1):38-44

Davey KR (1993) Linear-Arrhenius models for bacterial growth and death and vitamin denaturations. J Ind Microbiol 12(3-5):172-179

Deindoerfer FH (1957) Microbiological process discussion; calculation of heat sterilization times for fermentation media. Appl Microbiol 5(4):221-228

Deindoerfer FH, Humphrey AE (1959) Analytical method for calculating heat sterilization times. Appl Microbiol 7(4):256-264

Dubuis M-E, Dumont-Leblond N, Laliberté C, Veillette M, Turgeon N, Jean J, Duchaine C (2020) Ozone efficacy for the control of airborne viruses: Bacteriophage and norovirus models. PLoS ONE 15(4): 0231164

Elsworth R, Telling RC, Ford JWS (1955) Sterilization of air by heat. J Hyg 53(4):445-457

Feng S, Shen C, Xia N, Song W, Fan M, Cowling BJ (2020) Rational use of face masks in the COVID-19 pandemic. Lancet Respir Med 8(5):434-436

Fiorenzano Jr. A (1989) Sterilization system by means of high thermal gradient ducts. US Patent No. 4,877,990 
Froment GF, Bischoff KB, Wilde JD (2010) Chemical reactor analysis and design (Third.). Wiley, Hoboken, N.J. https://www.wiley.com/ en-us/Chemical+Reactor+Analysis+and+Design\%2C+3rd+Editi on-p-9780470565414.

Fujikawa H, Morozumi S, Smegare GH, Teixeira AA (2001) Thermal inactivation patterns of aspergillus niger spores in capillaries. Biocontrol Sci 6(1):17-20

Gallagher MJ, Gutsol A, Fridman A, Friedman G and Dolgopolsky A (2004) Non-thermal plasma applications in air sterilization. In: The 31st IEEE international conference on plasma science. Paper presented at the The 31st IEEE international conference on plasma science. Baltimore, MD, USA: IEEE, 198. https://ieeexplore.ieee. org/document/1339779

Garrett ER (1956) Prediction of stability in pharmaceutical preparations II: vitamin stability in liquid multivitamin preparations. J Am Pharm Assoc (scientific Ed) 45(3):171-178

Green DW, Perry RH (2008) Perry's chemical engineers' handbook (Eighth.). McGraw-Hill Education, New York. https://www.acade mia.edu/34738909/Perrys_Chemical_Engineers_Handbook_ 8thEd. Accessed 23 Aug 20

Guimera D, Trzil J, Joyner J, Hysmith ND (2018) Effectiveness of a shielded ultraviolet $\mathrm{C}$ air disinfection system in an inpatient pharmacy of a tertiary care children's hospital. Am J Infect Control 46(2):223-225

Humphrey AE (1960) Air sterilization. Advances in applied microbiology. Elsevier, pp 301-311. https://linkinghub.elsevier.com/retri eve/pii/S0065216408701321 Accessed 10 April 21

Hussein T, Hruška A, Dohányosová P, Džumbová L, Hemerka J, Kulmala M, Smolík J (2009) Deposition rates on smooth surfaces and coagulation of aerosol particles inside a test chamber. Atmos Environ 43(4):905-914

Kakaç S, Oskay R and Zhang HY (1988) Correlations for forced convection in ducts. In: Kakaç S, Bergles AE, Fernandes EO (eds) Two-phase flow heat exchangers. Springer, Dordrecht, 123-158. https://doi.org/10.1007/978-94-009-2790-2_4

Kern G and Krishnan M (2006) Virus removal by filtration: points to consider. BioPharm Int 19(10). https://www.biopharmin ternational.com/view/virus-removal-filtration-points-consider. Accessed $24 \mathrm{Feb} 21$

Kim J-M, Chung Y-S, Jo HJ, Lee N-J, Kim MS, Woo SH, Park S, Kim JW, Kim HM, Han M-G (2020) Identification of coronavirus isolated from a patient in Korea with COVID-19. Osong Public Health Res Perspect 11(1):3-7

Ko G, Burge H (2007) Removal of Serratia marcescens aerosols using an electrostatic precipitator. J Microbiol Biotechnol 17(10):1622-1628

Kowalski W, Bahnfleth W (2000) UVGI Design basics for air and surface disinfection. HPAC Heat Pip Air Cond 72:100-110

Kroeger PG (1967) Performance deterioration in high effectiveness heat exchangers due to axial heat conduction effects. In: Timmerhaus KD (ed) Advances in cryogenic engineering. Springer, Boston, pp 363-372. https://doi.org/10.1007/978-1-4757-0489-1_38.

Krosney MD, Peschke WOT and Reisenaur WE (2014) Air sterilization and disinfection apparatus and method. US Patent No. 8,900,519

Lai ACK, Cheung ACT, Wong MML, Li WS (2016) Evaluation of cold plasma inactivation efficacy against different airborne bacteria in ventilation duct flow. Build Environ 98:39-46

Levin PA, Angert ER (2015) Small but mighty: cell size and bacteria. Cold Spring Harbor Perspect Biol 7(7):a019216

Levine S (1956) Determination of the thermal death rate of bacteria. J Food Sci 21(3):295-301

Liu Y, Ning Z, Chen Y, Guo M, Liu Y, Gali NK, Sun L, Duan Y, Cai J, Westerdahl D, Liu X, Xu K, Ho K, Kan H, Fu Q, Lan K (2020) Aerodynamic analysis of SARS-CoV-2 in two Wuhan hospitals. Nature 582(7813):557-560
Luyben WL (1990) Process modeling, simulation, and control for chemical engineers. McGraw-Hill, New York

Madani TA, Abuelzein E-TME, Azhar EI, Al-Bar HMS (2014) Thermal inactivation of Alkhumra hemorrhagic fever virus. Adv Virol 159(10):2687-2691

Malaithao K, Kalambaheti T, Worakhunpiset S, Ramasoota P (2009) Evaluation of an electronic air filter for filtrating bacteria and viruses from indoor air. The Southeast Asian J Trop Med Public Health 40(5):1113-1120

Matias CJD (1999) Room air sterilization device. US Patent No. $5,874,050$

Matthews REF (1975) A classification of virus groups based on the size of the particle in relation to genome size. J Gen Virol 27(2):135-149

Michels HT, Keevil CW, Salgado CD, Schmidt MG (2015) From laboratory research to a clinical trial: copper alloy surfaces kill bacteria and reduce hospital-acquired infections. HERD Health Environ Res Design J 9(1):64-79

Nakamura H (1987) Sterilization efficacy of ultraviolet irradiation on microbial aerosols under dynamic airflow by experimental air conditioning systems. Bull Tokyo Med Dent Univ 34(2):25-40

Nunayon SS, Zhang HH, Jin X, Lai ACK (2019) Experimental evaluation of positive and negative air ions disinfection efficacy under different ventilation duct conditions. Build Environ 158:295-301

Pan M, Lednicky JA, Wu C-Y (2019) Collection, particle sizing and detection of airborne viruses. J Appl Microbiol 127(6):1596-1611

Pastuszka JS, Mucha W, Wlazło A, Lis D, Marchwińska-Wyrwał E, Mainka A (2019) The study of the sterilization of the indoor air in hospital/clinic rooms by using the electron wind generator. Int J Environ Res Public Health 16(24):1-11

Pfeifer VF, Chas V (1952) Continuous sterilization of media in biochemical processes. Ind Eng Chem 44(8):1940-1946

Popov VL, Tesh RB, Weaver SC, Vasilakis N (2019) Electron microscopy in discovery of novel and emerging viruses from the collection of the world reference center for emerging viruses and arboviruses (WRCEVA). Viruses 11(5):477

Prehn F, Timmermann E, Kettlitz M, Schaufler K, Günther S, Hahn V (2020) Inactivation of airborne bacteria by plasma treatment and ionic wind for indoor air cleaning. Plasma Processes Polym 17(9):2000027

Public Health England (2020) COVID-19: infection prevention and control guidance. Guidance. England: Public Health England, 51. Available at: https://www.buckshealthcare.nhs.uk/Downl oads/AA_COVID_19/COVID-19\%20IPCT\%20PPE/200427_ COVID-19_Infection_prevention_and_control_guidance.pdf. Accessed 16 Sep 20.

Rahn O (1945) Physical methods of sterilization of microörganisms. Bacteriol Rev 9(1):1-47

Reponen T, Grinshpun SA, Conwell KL, Wiest J, Anderson M (2001) Aerodynamic versus physical size of spores: measurement and implication for respiratory deposition. Grana 40(3):119-125

Riediker M, Tsai D-H (2020) Estimation of viral aerosol emissions from simulated individuals with asymptomatic to moderate coronavirus disease 2019. JAMA Netw Open 3(7):10

Roberts PL, Feldman P, Crombie D, Walker C, Lowery K (2010) Virus removal from factor IX by filtration: Validation of the integrity test and effect of manufacturing process conditions. Biologicals 38(2):303-310

Santagostino E, Mannucci P, Gringeri A, Azzi A, Morfini M, Musso R, Santoro R, Schiavoni M (1997) Transmission of parvovirus B19 by coagulation factor concentrates exposed to 100 degrees $C$ heat after lyophilization. Transfusion 37(5):517-522

Sauerbrei A, Wutzler P (2009) Testing thermal resistance of viruses. Adv Virol 154(1):115-119 
Schneider B, Becker M, Brackmann H-H, Eis-Hübinger A (2004) Contamination of coagulation factor concentrates with human parvovirus B19 genotype 1 and 2. Thromb Haemost 92(10):838-845

Schoeman D, Fielding BC (2019) Coronavirus envelope protein: current knowledge. Virol J 16(1):69

Schubert WW, Beaudet RA (2011) Determination of lethality rate constants and D-values for heat-resistant Bacillus spores ATCC 29669 exposed to dry heat from $125^{\circ} \mathrm{C}$ to $200^{\circ} \mathrm{C}$. Astrobiology 11(3):213-223

Shelton-Davenport M, Pavlin J, Saunders J, Staudt A (2020) Airborne transmission of SARS-CoV-2: proceedings of a workshop--in brief. http://www.ncbi.nlm.nih.gov/books/NBK563528/. Accessed 10 April 21.

Singh R, Kim J, Shepherd MW, Luo F, Jiang X (2011) Determining thermal inactivation of Escherichia coli O157:H7 in fresh compost by simulating early phases of the composting process. Appl Environ Microbiol 77(12):4126-4135

Sleicher CA, Rouse MW (1975) A convenient correlation for heat transfer to constant and variable property fluids in turbulent pipe flow. Int J Heat Mass Transf 18(5):677-683

Smets W, Moretti S, Denys S, Lebeer S (2016) Airborne bacteria in the atmosphere: presence, purpose, and potential. Atmos Environ 139:214-221

Streifel AJ, Vesley D, Rhame FS, Murray B (1989) Control of airborne fungal spores in a university hospital. Environ Int 15(1-6):221-227
Tsuji K, Harrison SJ (1978) Dry-heat destruction of lipopolysaccharide: dry-heat destruction kinetics. Appl Environ Microbiol 36(5):710-714

Wang DI-C, Scharer J, Humphrey AE (1964) Kinetics of death of bacterial spores at elevated temperatures. Appl Microbiol 12(5):451-454

Warnes SL, Little ZR, Keevil CW (2015) Human coronavirus 229E remains infectious on common touch surface materials. Mbio 6(6):e01697-e1715

Weiss IM, Muth C, Drumm R, Kirchner HOK (2018) Thermal decomposition of the amino acids glycine, cysteine, aspartic acid, asparagine, glutamic acid, glutamine, arginine and histidine. BMC Biophys 11(2): 15

Whitmarsh JM (1954) Continuous sterilization of fermentation media. J Appl Bacteriol 17(1):27-30

Wilkes AR, Benbough JE, Speight SE, Harmer M (2000) The bacterial and viral filtration performance of breathing system filters*: performance of filters. Anaesthesia 55(5):458-465

Yap TF, Liu Z, Shveda RA, Preston DJ (2020) A predictive model of the temperature-dependent inactivation of coronaviruses. Appl Phys Lett 117(6):060601 